\title{
Development of KKNI Based Materials Integrated Character Value in Indonesian Prehistoric Course
}

\author{
Arfan Diansyah ${ }^{1}$, Flores Tanjung ${ }^{2}$, Abdul Haris Nasution ${ }^{3}$. \\ \{ arfandiansyah@unimed.ac.id ${ }^{1}$, flores_tanjung@yahoo.com², abdharisnasution@unimed.ac.id ${ }^{3}$ \}
}

Universitas Negeri Medan, North Sumatera, indonesia ${ }^{1,2,3}$

\begin{abstract}
This research aims to develop integrated Indonesian Prehistoric teaching materials based on KKNI character values. This study uses a research and development (R\&D) method with the ADDIE (analysis, design, development, implementation, and evaluation) model from Dick and Carry. Data collection techniques using a questionnaire. The results showed that the assessment by the eye specialist indicated a percentage of achievement of $77.22 \%$ in the first stage and $85.33 \%$ in the second stage. The results of the assessment by media experts showed a percentage of achievement of $92 \%$. The results of the assessment by design experts showed a percentage of achievement of $80 \%$. The percentage of small group student assessment achievement was $83 \%$ and the percentage of small group student achievement evaluation was $81.86 \%$. Based on the percentage of achievement from material experts, media experts, design experts, and student assessments, the developed teaching materials are categorized as suitable teaching materials.
\end{abstract}

Keywords: Teaching materials, KKNI, Character value, Prehistoric, Indonesia

\section{Introduction}

Changing global conditions require the need to re-formulate what is essentially given to students. Educational institutions are a vehicle that is believed to develop the personality and social adaptation of students in improving skills following current global needs. Along with the development of science and technology, education experiences a dynamic process in adapting to existing situations and conditions. One form of educational innovation is to instill character education in various educational processes. Given the importance of character education, especially in efforts to build strong human resources, the application of character education must be carried out with careful planning. The application of the IQF curriculum is an attempt to re-arrange education in higher education institutions by placing character as a dimension in national education associated with the intellect that is reflected in the achievement of special learning.

The application of character in educational institutions must be integrated into the course as part of the nation's character building. To be able to achieve these competencies it is necessary to develop an integrated teaching material with character values under the content of the subjects being studied. Today almost all historical writings tend to focus only on the facts of events without much reviewing the meaning contained therein. So that the historical picture that arises in the minds of students is only memorizing facts and historical events without having meaning [5]. The need to develop prehistoric teaching materials based on KKNI 
integrated character values is based on the lack of teaching books that display historical content that is full of history. Most of the history books that contain a lot of facts that make students immersed in facts so that students find it difficult to interpret historical events. Whereas interpreting historical events is the basis for acting as fully human beings who are callous, wise, conscientious and critical in all respects and obtain advanced national insight.

Teaching material is one source that can be used that serves to support the learning process. Teaching material is a set of material arranged systematically both in writing and unwritten that is used to help the teacher/instructor in carrying out learning activities in class both teaching material containing knowledge, skills, and attitudes that students must learn to achieve predetermined competency standards [8]. Prehistoric teaching material is a set of material that has been compiled to explain through writing related to historical events in prehistoric times in Indonesia. Presenting historical events through writing such as teaching materials is not easy, historical events should be written by looking at the characteristics of a historical event. In a historical event it should be shown the elements, namely: the form of the event (what), the culprit (who), the place of the event (where), the time of the event (when), the element of why or the background of the occurrence event (why), and finally the question regarding how it might have happened (how). Naturally, explanations relating to why and how are especially important concerns in historical information, because this is where the specifics of historical characteristics will be seen [4].

The Law number 20 of 2003 concerning the National Education System (UU Sidiknas) point 3 states "national education functions to develop and shape the dignified character and civilization of the nation in the context of educating the life of the nation, aiming at developing the potential of students to become human beings of faith and piety to God Almighty, noble, healthy, knowledgeable, capable, creative, independent, and become citizens of a democratic and responsible". The purpose of national education is the formulation of the quality of Indonesian people that must be developed by each education unit. The formulation of the objectives of national education should be the basis in the development of cultural education and national character [2].

At present, the strengthening of character values in learning, especially learning history is very important. Many problems that occur in Indonesia today lead to unproductive and destructive behavior. National and moral values among students have reached an alarming level[1]. Various efforts related to the development of cultural and character education have been carried out by the government starting in the Old Order with the Nation Character Building to reform by launching Character Education. However, if you look at the current worrisome conditions of Indonesian society such as corruption, violence, theft, mass fighting, it seems necessary to find alternative solutions to the problem.

The alternative solutions to overcome problems regarding cultural problems and national character certainly through education. But the problem is how character values can be integrated into the learning process. One way is to integrate character values into teaching materials, where the character values are adjusted to the content of the teaching material to be studied. States that there is a need for adaptation of character education in textbooks that will be used by teachers in the learning process. The history books that are available today show more material without the values contained in the historical material, even though studying history is learning an event that is full of values [6].

Hasan revealed again that in the new paradigm of historical education, the understanding of stories and memorization of facts is not abandoned, but the understanding of stories and memorization of facts needs to be expanded into knowledge [3]. Understanding of historical thinking, historical skills, their use in learning and producing historical stories, the exploration 
of values and the application of selected values are useful for present and future life. The values of local wisdom can also be used as a basis for character education in educational institutions. In line with that Hermanus in his presentation at the National Symposium on Teaching History (2019) with the theme "Revolution Learning History in Indonesia" states that teaching history must be changed from mere text to thematic by providing a simulation of history to students. Historical education is directed to instill humanist values such as selfinterest, sympathy, humanity, and religiosity which are part of the form of civic nationalism.

The values above are part of the values in character education. Therefore, to build a mental character of Indonesian society, bias can be done by integrating character values into historical teaching materials under the material taught in the learning process. This past knowledge is valuable wealth that can be used as a foundation for the formation of young generation characters as well as character-based learning materials [7]. Based on the above problems, research on the development of teaching materials based on KKNI integrated character values in Indonesian Prehistoric courses is important to do.

\section{Methods}

Research on KKNI-based teaching material development integrated character values in Indonesian Prehistoric courses using research and development design or called Research and Development (R\&D). This study uses the ADDIE development model developed by Dick and Carry. The ADDIE model has 5 stages of development namely the Analysis, Design, Development, Implementation, and Evaluation stages. However, in this study, only 4 stages were carried out namely Analysis, Design, Development, and Implementation. The location of the study was conducted in the Department of Historical Education, Faculty of Social Sciences, Medan State University. The assessment of teaching material products developed is carried out by material experts, media experts, and design experts as well as assessments by students. Data collection techniques were carried out using questionnaires and interviews. The data collection instrument used a questionnaire.

\section{Results and discussion}

The development of teaching materials based on KKNI integrated character values in Indonesian Prehistoric courses is an effort to internalize character values into Indonesian Prehistoric material. The development of teaching materials is done by using the ADDIE development model of Dick and Carry with the development stages of the Analysis, Design, Development, Implementation, and Evaluation stages. However, in this study, the development stage did not reach the evaluation stage.

In the analysis phase, researchers conducted field studies and literature studies. From the results of the field study obtained information that the lack of internalization of character values in the history learning process of Indonesian Prehistoric courses. The textbooks used are good, but not yet full of grades. The attitude competency that must be possessed by students who take Indonesian Prehistoric courses is to be able to formulate the values of wisdom from a pre-literate human culture that is useful for present and future life. On that basis, the development of prehistoric teaching materials that integrated character values becomes important to be developed. 
At the planning stage (design), researchers determine learning outcomes, determine learning objectives and indicators, prepare draft books and prepare drawings. Learning achievements in the realm of attitudes that must be possessed can internalize religious values, justice, and hard work from the beginning of the growth and development of the prehistoric Indonesian society and culture. Indicators of success can be seen from the ability of students to internalize the values of wisdom from the lives of prehistoric communities such as religious, justice, cooperation and actualized in everyday life. The initial book prepared consists of seven topics. The drawings prepared were sourced from drawings from expert research and were also documented by regional and national archeological institutions.

At the development stage, researchers begin to develop teaching materials. Teaching material is obtained from literature studies based on the latest research journals and books that examine prehistoric events in Indonesia. Teaching materials that have been developed are then validated to get teaching materials that have good quality. Validation is done by requesting an assessment from a material expert, an assessment from a media expert and an assessment from a design expert. Expert assessment of the material includes aspects of content, aspects of presentation and aspects of language.

The results of the assessment of the material experts showed that the quality of the material from the teaching materials that were developed included in both categories in the rating scale 1-5, this result was based on the score of the material expert assessment stage one of 3.8 for the content aspect, 4.2 for the presentation aspect, and 3,6 for linguistic aspects. The results of the assessment by the second stage material experts obtained a score of 4.4 for the content aspect, 4.4 for the presentation aspect, and 4 for the linguistic aspect.

Table 1. Results of expert material assessment stage 1 and 2 on the content aspect

\begin{tabular}{clcccc}
\hline no & \multicolumn{1}{c}{ indicator } & \multicolumn{2}{c}{ score } & \multicolumn{2}{c}{ category } \\
& & stage 1 & stage 2 & stage 1 & stage 2 \\
\hline 1 & conformity of material and learning & 4 & 5 & good & very good \\
& outcomes & & & & \\
2 & material accuracy & 4 & 4 & good & good \\
3 & material updates & 4 & 4 & good & good \\
4 & encourage curiosity & 4 & 4 & good & good \\
5 & insert character values in the material & 3 & 5 & very good & very good \\
& $\quad 19$ & 22 & & good & good \\
& $\quad$ toverage & 3,8 & 4,4 & & \\
\hline
\end{tabular}

Based on the table above, in stage one, the total score of the results of the material expert assessment on the content aspect is 19 , with an average score of 3.8. In stage two, the total score of material experts in the aspect of content was 22 with an average score of 4.4. This result shows that based on expert material assessment, teaching materials developed in the aspect of content are included in the Good category.

Table 2. Results of the expert material assessment of stage 1 and stage 2 on the presentation aspects 


\begin{tabular}{|c|c|c|c|c|c|}
\hline \multirow[t]{2}{*}{ no } & \multirow[t]{2}{*}{ indicator } & \multicolumn{2}{|c|}{ score } & \multicolumn{2}{|c|}{ category } \\
\hline & & stage 1 & stage 2 & stage 1 & stage 2 \\
\hline 1 & $\begin{array}{l}\text { the appearance of material rashes } \\
\text { outcomes }\end{array}$ & 5 & 5 & very good & very good \\
\hline 2 & presentation under the objectives & 4 & 4 & good & good \\
\hline 3 & $\begin{array}{l}\text { presentation requires students to think } \\
\text { actively }\end{array}$ & 4 & 4 & good & good \\
\hline 4 & $\begin{array}{l}\text { presentation requires students to explore } \\
\text { information }\end{array}$ & 4 & 4 & good & good \\
\hline 5 & $\begin{array}{l}\text { presentation of images facilitates } \\
\text { student understanding }\end{array}$ & 4 & 5 & good & very good \\
\hline & total & 21 & 22 & & \\
\hline & average & 4,2 & 4,4 & good & good \\
\hline
\end{tabular}

Based on the above table, in stage one, the total score of the results of the material expert assessment on the presentation aspect is 21 , with an average score of 4.2 . In stage two, the total score of material experts in the presentation aspect is 22 with an average score of 4.4. This result shows that based on expert material assessment, teaching materials developed in the presentation aspect are included in the Good category.

Table 3. Results of the expert material assessment of stage 1 and stage 2 on the graphic aspect

\begin{tabular}{clcccc}
\hline no & \multicolumn{1}{c}{ indicator } & \multicolumn{2}{c}{ score } & \multicolumn{2}{c}{ category } \\
& & stage 1 & stage 2 & stage 1 & stage 2 \\
\hline 1 & the accuracy of sentence structure & 4 & 4 & good & good \\
2 & suitability of language with student & 3 & 4 & very good & good \\
& development & & & & \\
3 & conformity with language rules & 3 & 4 & very good & good \\
4 & dialogical and interactive & 4 & 4 & good & good \\
5 & communicative & 4 & 4 & good & good \\
& $\quad$ total & 18 & 20 & & good \\
\hline
\end{tabular}

Based on the table above, in stage one, the total score of the results of the material expert assessment on the graphic aspect is 18, with an average score of 3.6. In stage two, the total score of the material expert's score in the aspect of the graphic is 20 with an average score of 4. This result shows that based on the assessment of material experts, teaching materials developed in the aspect of a graphic are included in the Good category. The results of the assessment from the media and design experts for the teaching material being developed are also included in both categories. This is based on the score of a media expert assessment score of 4.6 and a design expert assessment score of 4 on a rating scale of 1-5.

Table 4. Results of assessment by media experts 


\begin{tabular}{clcc}
\hline no & \multicolumn{1}{c}{ indicator } & score & category \\
\hline 1 & limitations of text and writing & 4 & good \\
2 & the display quality of teaching materials & 5 & very good \\
3 & ease of use & 5 & very good \\
4 & color selection accuracy & 4 & good \\
5 & accuracy in using images & 5 & very good \\
& total & 23 & good \\
\hline
\end{tabular}

Based on the results of the assessment by media experts as illustrated in the table above, a score of 23 is obtained with an average score of 4.6. These results indicate that the side view of the developed teaching material media is included in the Very Good category.

Table 5. Results of design expert assessments

\begin{tabular}{clcc}
\hline No & \multicolumn{1}{c}{ Indicator } & Score & Category \\
\hline 1 & Size of teaching materials & 4 & Good \\
2 & Cover design of teaching materials & 4 & Good \\
3 & Design contents of teaching materials & 4 & Good \\
4 & Paper quality & 4 & Good \\
5 & Design image sizes on teaching materials & 4 & Good \\
& $\quad$ Total & 20 & Good \\
\hline
\end{tabular}

Based on the results of the design expert assessment, the total score on the aspect of graphic worthiness has obtained a score of 20 , with an average score of 4 . These results indicate that from the aspect of graphics (design) the teaching materials developed are included in the Good category. Based on the results of the assessment of material experts, media experts, and design experts, the validation stage in developing Indonesian Prehistoric teaching materials as a whole is categorized as good. From these results, the developed teaching material is ready to be implemented.

Indonesian Prehistoric teaching materials based on KKNI integrated character values were developed to help students internalize and actualize the character values that are behind the discourse of the great events of the Indonesian people during prehistoric times. The results of the validation test by material experts, media experts, and design experts show that the teaching materials developed are included in both categories. Thus the teaching material that has been developed is feasible to be implemented.

The implementation phase is intended to see students' responses to the teaching materials that are developed and at the same time test the feasibility of the teaching materials that are developed. The assessment stage conducted by students consists of assessments by small groups and assessments by large groups. The results of the assessment of small group students amounted to 4.15 on a scale of $1-5$. These results indicate that the developed instructional materials get good grades based on student responses. Student assessment results from large groups showed a score of 4.09 on a rating scale of 1-5. These results indicate that the results of the assessment of students from large groups based on students' responses to the teaching materials developed are included in either category.

The results of the assessment both by material experts, media experts, design experts and assessments by students are then converted into a score of percentage of achievement worthiness to see the feasibility of the teaching material developed. The results of the 
assessment by the optometrists showed a percentage of achievement of $77.22 \%$ in the first stage and $85.33 \%$ in the second stage.

Table 6. Feasibility of teaching materials is based on material expert judgment stage 1

\begin{tabular}{ccccc}
\hline no & feasibility aspects & average & $\begin{array}{c}\text { percentage of } \\
\text { achievement }\end{array}$ & category \\
\hline 1 & content eligibility & 3.8 & $76 \%$ & eligible \\
2 & presentation eligibility & 4.2 & $84 \%$ & eligible \\
3 & graphic eligibility & 3.6 & $72 \%$ & Very eligible \\
& total & & $232 \%$ & eligible \\
\hline
\end{tabular}

Based on the table above, the percentage of content worthiness of $76 \%$ is obtained with the feasible category, the percentage of eligibility for presentation is $84 \%$ with the proper category, and the percentage of achievement of language eligibility is $72 \%$ with the category of quite feasible. The average percentage of the feasibility of teaching materials developed based on the aspect of material eligibility was $77.22 \%$. Thus teaching material developed in the material aspect is categorized as Eligible.

Table 7. Feasibility of teaching materials is based on material expert judgment stage 2

\begin{tabular}{llccc}
\hline no & feasibility aspects & average & $\begin{array}{c}\text { percentage of } \\
\text { achievement }\end{array}$ & category \\
\hline 1 & content eligibility & 4,4 & $88 \%$ & eligible \\
2 & presentation eligibility & 4.4 & $88 \%$ & eligible \\
3 & graphic eligibility & 4 & $80 \%$ & eligible \\
& total & & $256 \%$ & eligible \\
\hline
\end{tabular}

Based on the table above, the percentage of content worthiness achievement is $88 \%$ with a decent category, the percentage of eligibility for presentation is $88 \%$ with a decent category, and the percentage of language worthiness achievement is $80 \%$ with a feasible category. The average percentage of the feasibility of teaching materials developed based on the aspect of material eligibility was $85.33 \%$.

Table 8. Feasibility of teaching materials is based on media expert judgment

\begin{tabular}{llccc}
\hline no & feasibility aspects & average & $\begin{array}{c}\text { percentage of } \\
\text { achievement }\end{array}$ & category \\
\hline 1 & display & 4.6 & $92 \%$ & very eligible \\
\hline
\end{tabular}

Based on the table above, the percentage score obtained by the evaluation of media experts on the display aspect is $92 \%$. Based on these results it is concluded that based on the assessment of media experts on the developed teaching materials included in the Very Eligible category.

Table 9. Feasibility of teaching materials based on design expert judgment 


\begin{tabular}{llccc}
\hline no & feasibility aspects & average & $\begin{array}{c}\text { percentage of } \\
\text { achievement }\end{array}$ & category \\
\hline 1 & graphics & 4. & $80 \%$ & eligible \\
\hline
\end{tabular}

Based on the table above, obtained a percentage score of the achievement of design expert ratings on the aspect of the graphic by $80 \%$. Based on these results it is concluded that based on the design expert's judgment on the developed teaching material included in the Eligible category.

Table 10. Feasibility of teaching materials based on student assessment

\begin{tabular}{cccccccc}
\hline no & feasibility aspects & \multicolumn{2}{c}{ average } & \multicolumn{2}{c}{ percentage of } & \multicolumn{2}{c}{ category } \\
& & & & \multicolumn{2}{c}{ achievement } & & \\
& & $\mathrm{sg}$ & $\mathrm{lg}$ & $\mathrm{sg}$ & $\mathrm{lg}$ & $\mathrm{sg}$ & $\mathrm{lg}$ \\
\hline 1 & student response & 4.15 & 4.09 & $83 \%$ & $81.86 \%$ & eligible & eligible \\
\hline
\end{tabular}

Based on the table above, the percentage score obtained by the assessment of small group students reached $83 \%$ (feasible) and the percentage of achievement ratings for large group students was $81.86 \%$ (feasible). Thus it can be concluded that teaching materials developed are based on student responses both in small groups (SG) and large groups (LG) included in the Eligible category. From the results of the feasibility assessment by referring to the percentage of achievement both from material experts, media experts, design experts and assessments by students, it can be concluded that the Indonesian Prehistoric teaching materials developed are included in the feasible category.

Learning from human life in prehistoric times in Indonesia, there are the values of character and culture as relics as outlined in this teaching material. The values are as follows: (1) religious values: Religious values are obtained from the beliefs of prehistoric societies in an authority over them (animism and dynamism). One that can be interpreted from this belief is that in prehistoric times humans tried to limit their behavior. Attitude to limit behavior is reflected in an attitude of respect for others (respect for ancestors), respect as the basis of religion, (2) cooperation value. The value of cooperation can be taken from the activities of prehistoric Indonesian people, namely the existence of group life, where they work together for the common good (hunting and farming).

Besides that, they also jointly set up buildings or houses for their homes. The megalithic traditions that we still encounter today show that at that time the cooperation system was known in social life, (3) fairness value. Fairness value can be found starting during hunting and farming. At that time there had been a division of tasks according to gender, abilities, and expertise. The duties of a man differed from that of a woman. During the passage of justice, it is apparent that everyone will get the right to an obligation based on their expertise, and (4) the value of deliberation. The value of deliberation developed by prehistoric societies is as in the case of electing leaders. Leaders are chosen based on the results of deliberation but accompanied by certain expertise. That becomes the basis for the growth and development of democratic life principles.

The above values are in line with the formulation of attitudes that must be possessed by each graduate in accordance with the KKNI, that is, the religious values contained in the first formulation of attitudes that are devoted to God Almighty and able to show religious attitudes; the value of cooperation can be found in the formulation of the sixth attitude namely cooperation and social sensitivity and concern for the community and the environment. The 
value of justice and deliberation is contained in the formulation of attitudes that upholds law enforcement and has the spirit to prioritize the interests of the nation and the wider community.

\section{Conclusion}

Indonesian Prehistoric teaching materials developed based on integrated KKNI character values contain material content that is adjusted to achieve learning objectives following the learning outcomes of the course. Teaching material developed contains the latest facts on the development of Prehistoric research in Indonesia. The presentation of material in this teaching material is quite simple and is equipped with pictures that make it easy for students to understand the information conveyed. The character values presented in this teaching material are integrated into every historical fact related to prehistoric human activities. Based on the percentage of achievement from material experts, media experts, design experts, and student assessments, the developed teaching materials are categorized as suitable teaching materials.

Acknowledgments. Praise and gratitude the authors pray to God Almighty for all the abundance of grace and blessings, so that the author can finish this article with the title "Development of KKNI-Based Teaching Materials Integrated Character Values in Indonesian Prehistoric Courses". On this occasion, I would like to thank the organizing committee of the International Conference on Social Sciences and Interdisciplinary Studies (ICSSIS).

\section{References}

[1] Aman. Aktualisasi Nilai-Nilai Kesadaran Sejarah dan Nasionalisme dalam Pembelajaran Sejarah di SMA. Jurnal Pendidikan Karakter, 4(1). (2014)

[2] Hasan, H. Pendidikan Sejarah Indonesia Isu dalam Ide dan Pembelajaran. Bandung: Rizqy Press (2012)

[3] Hasan, H. Pendidikan Sejarah dalam Mempersiapkan Generasi Emas; Suatu Perubahan Paradigma Sejarah dengan Referensi pada Kurikulum 2013. Banjarmasin (2015).

[4] Ismaun dkk. Pengantar Ilmu Sejarah. Bandung: Departemen Pendidikan Sejarah dan APPS (2016).

[5] Kuswono. No TiPengembangan Modul Sejarah Pergerakan Indonesia Terintegrasi Nilai Karakter Religius. tle. Jurnal Historia, 5(1), 33 (2017).

[6] Marzuki. Pengintegrasian pendidikan karakter dalam pembelajaran di sekolah. Jurnal Pendidikan Karakter, (2), 33-44 (2012).

[7] Susilo, A. D. Peran Guru Sejarah Abad 21 Dalam Menghadapi Tantangan Arus Globalisasi. Jurnal Historia, 2(1), 49 (2018).

[8] Wasino. Menyusun Bahan Ajar yang Cerdas. Semarang. Lembaga Pengawas Kualitas Pendidikan (2010) 